\title{
比較と処理の水準が再生に及ぼす影響 ${ }^{1)}$
}

\author{
伊藤真利子・綾 部 早 穂 (筑波大学)
}

Effects of comparison and the levels of processing on recall memory

Mariko ITOH and Saho AYABE-KANAMURA (University of Tsukuba)

The self-choice effect states that self-selected items are more likely to be remembered than items selected by an experimenter. It has been suggested that the act of comparing among items in the self-choice condition is necessary for the self-choice effect to emerge (Itoh, Ayabe-Kanamura, \& Kikuchi, 2012), but it is also possible that semantic characteristics accessed within the comparison process could facilitate memory (i.e., a levels-of-processing effect). During the incidental-study phase of our experiment, participants made comparisons of two words based on either semantic-level or non-semantic-level characteristics or made judgments about a single word at either a semantic-level or non-semantic-level. Recall performance showed a levels-ofprocessing effect for both conditions. More importantly, the performance results indicated a facilitating effect of making a comparison regardless of the level-of-processing. These results suggest that making comparisons between items during selection, rather than level-of-processing alone, contributes to the self-choice effect on memory.

Key words: self-choice effect, comparison between items, level-of-processing

記銘項目が実験者によって割り当てられる場合よりも，実験参加者自身により選択される場合のほうが記 憶保持は優れる。この自己選択効果の生起には, 選択肢項目間の相対比較が必要である可能性が示唆されて いるが（伊藤・綾部・菊地，2012），相対比較の際に意味水準での特徴にアクセスすることが記憶を促した 可能性は否定できない（処理水準効果）。本研究の偶発学習段階において実験参加者は，意味水準か非意味 水準の特徴に基づいて二つの選択肢項目間の相対比較を行うか，単独の項目に対して意味水準か非意味水準 で判断を行った。 その結果，二つの項目間で相対比較が行われた場合にも，単独の項目に対して判断が行わ れた場合にも，再生成績における処理水準効果が認められた。さらに重要なことに，処理水準にはかかわら ず項目間の相対比較による記憶の促進が認められた。よって，記憶における自己選択効果の生起には選択の 際の相対比較が必要であり, 処理水準効果のみが貢献しているとは言えない可能性が示唆された.

キーワード：自己選択効果，選択肢間の比較，処理水準

日常生活において，覚えておくべき情報を自ら選択す ることはしばしば行われる，選択することが記憶に及ぼ す影響を明らかにすることは人の記憶行動を理解するた めに必要である. Perlmuter, Monty, \& Kimble (1971) は，記銘項目を自分で選択できた場合（自己選択）のほ うが，記銘項目を他者から割り当てられた場合（強制選 択）に比べて記憶保持が優れることを報告しており，こ の現象は高橋（1989）により自己選択効果（self-choice effect）と命名された.

自己選択効果の実験手続きでは, 意罒学習事態におい て記銘候補として複数の項目を提示された際に，自己選 択条件では実験参加者が記銘項目を自由に選択できる が，強制選択条件では決められた項目を選択するように 求められる. 有意味な記銘材料（例えば, リンゴ, イチ ゴ）を用いた場合には，再生テスト（Takahashi, 1992） や再認テスト（Monty, Perlmuter, Libon, \& Bennet, 1982;

1）本研究は，日本心理学会第76回大会で発表された.
Perlmuter \& Monty, 1982；高橋，1993）において，自己 選択効果が認められている。しかし，無意味な記銘材料 （例えば，アマナ，イトク）を用いた場合の自己選択効 果は, 再認テストにおいてのみ認められ, 再生テストで は認められないことが報告されている（Takahashi, 1992; 高橋, 1993).この結果から，選択がどのように 再生と再認を促すかをそれぞれ区別して説明する必要が あり, 少なくとも再生での自己選択効果の生起には項目 の意味処理が必要であると考えられる.

自己選択がどのようにして再生と再認を促すかについ て, 符号化方略説は次のように説明している（高橋, 1997）。すなわち，自己選択条件においてはテストに備 えて意味的に関連づけやすい項目を自由に選択していく ことができるため，主観的体制化のように選択項目間の 関係情報（relational information）の符号化が促され (Einstein \& Hunt, 1980), 再生成績が向上する.また, 自己選択条件においては選択肢項目間の差異を処理する ことで, 項目情報（item-specific information）の符号 
化が促され (Einstein \& Hunt, 1980), 新奇項目と旧項 目とを区別しやすくなり再認成績が向上するという（高 橋, 1997).

従来，自己選択効果の研究における“選択” とは，意 図学習事態での記銘項目の主観的な選択を指してきた (レビューとして平野, 2000; 高橋, 1997; 渡邊, 2011). しかし, 偶発学習事態においても自己選択効果は生起し (Hirano \& Ukita, 2003), また, 実験者から与えられた 基準（例えば, “縞のある動物”）に従った客観的な選択 であっても, 主観的な選択と同等の再生成績が得られた (Watanabe, 2001)。これらの結果から, 符号化方略説で 想定されるように, 実験参加者自身が意図学習事態にお いて関連づけのしやすい項目を主観的に選択できること が, 選択による記憶の促進のために必要とは限らない可 能性が示唆された．また，符号化方略説では自己選択条 件において関連づけやすい項目どうしが選択されると想 定するため, 再生時には関連づけられた選択項目どうし が連続して想起されるはずだが，実際には同じ選択試行 で提示された選択項目と非選択項目とが連続して再生さ れやすかった（Hirano \& Ukita, 2003).

その後, 選択項目間ではなく選択項目と非選択項目と の関連づけが再生を促すという結合処理説（Hirano \& Ukita, 2003), 多重手がかり説 (Watanabe, 2001; Watanabe \& Soraci, 2004）が提案された.つまり，自己選択 の過程において, 選択項目と非選択項目とが比較のため に同時に活性化されて結びつけられることで, 再生時に は非選択項目が選択項目の手がかりとして働き，再生を 促進させる可能性があるという。この説明に一致して, 自己選択条件においてのみ非選択項目を手がかりとして 提示されることで選択項目の再生が促された（Watanabe \& Soraci, 2004). 加えて, 非選択項目の記憶にお いても自己選択効果が認められること（Monty et al., 1982）も説明可能である. さらに近年では, 選択項目 と非選択項目の関係性に注目した別の説明として, 統合 仮説が提案されている（Toyota, 2013; 豊田・小林, 2009; 豊田・小林・平野，2007）。すなわち，比較の基 準（例えば，“自分の好きなほう”）に照らして選択項目 を明確に決定できる場合には, 選択項目が認知構造に統 合されやすくなり，選択項目の再生率が向上すると説明 されている.

このように, 自己選択条件において比較の過程で選択 項目と非選択項目とがどのような処理を受けるかが, 自 己選択効果の生起にとって重要であるととらえられてい る（伊藤・綾部・菊地，2012）. 選択項目を何に対して 関連づけるか（結合処理説と多重手がかり説では “非選 択項目”, 統合仮説では “認知構造”) を明らかにするこ とが重要ではあるものの, まず最初の段階として, 項目 を意味水準において処理すること（Craik \& Lockhart,
1972）が自己選択効果の生起にどの程度影響するかを 明確にしておく必要がある。これは, 自己選択効果の生 起が, 選択に特有の処理（相対比較など）とそれ以外の 要因（ここでは, 処理水準）にどの程度依存するかとい う問題であり，仮に自己選択効果が処理水準によって多 大な影響を受けるのであれば，“選択”による記憶の促 進現象とはみなせないお㧈そもある。

異なる処理水準において選択条件を設定した研究とし ては, Hirano \& Ukita（2003, 実験2）が挙げられる. 実験参加者は, “覚えやすさの評定” (意味水準), また は“発音しやすさの評定” (非意味水準) を目的として 単語を選択した (強制, 自己選択)。選択, 非選択項目 の再生テストの結果, 処理水準間で自己選択効果の程度 に違いがなかった，ただし，この手続きにおいては，選 択の“目的”が異なる水準で設定されたが，“比較”す る際の処理水準が直接的に統制されたわけではない。こ れに対して, 伊藤他 (2012, 実験2）の実験参加者は, 例えば, “より速いほう” (意味水準)，または“「あ」の 母音をより多く含むほう” (非意味水準)を選択した (これらのほかに, “下線の引かれたほう”を選択する強 制選択条件，“好ましいほう”を選択する自己選択条件 が加えられ，1要因 4 水準計画であった). 結果として, 比較の水準による選択項目の再生率の違いは認められ ず，いずれも強制選択条件を上回った。ただし，伊藤他 （2012，実験2）の結果では，再生率においては統計的 に有意な処理水準効果が確認されず，水準が十分に操作 されなかった可能性も否定できない，加えて，強制選択 条件では判断を伴わないために（下線の引かれた語を冊 子に記入するのみ), 他の 3 条件よりも再生率が低かっ たかもしれない.

そこで, 本研究では, 意味または非意味水準において 項目間の比較を行う自己選択条件に加えて, 意味または 非意味水準での比較を行わない強制選択条件を設定し, 強制選択条件では単独の項目に対してyes/noの判断を 求めた.これにより, 伊藤他 (2012) の未解決点につ いては, 比較が行われない条件において従来どおりの処 理水準効果を確認できるはずであり, 判断を行うこと自 体ではなくそれぞれの水準において比較することによる 記憶の促進を検討できると考えられた，比較の際の処理 水準が自己選択効果の生起に影響しないとすれば，意味 水準か否かにかかわらず同程度の自己選択効果が得られ ると予想された。

\section{方法}

\section{実験参加者}

プログラミング入門を受講している大学生 58 名が集 団で実験に参加し, このうち5名は記憶テストが行われ ることを予期したり, 偶発学習段階において判断の䛊り 
や入力漏れが一つの条件の半数以上の試行で認められ, その他の実験参加者のデータと同質であるとみなされな かったために除外された。合計53名（男性 34 名，女性 19 名, 平均年齢 19.0 歳, $S D=0.5 ）$ のデータについて分 析を行った。

\section{デザイン}

処理水準 (非意味, 意味), および選択条件 (強制, 自己）を参加者内要因とする2要因計画であった。

\section{装置}

すべての段階は, Hot Soup Processor Ver. 3.1で作成 されたプログラムをパーソナルコンピュータ上で動かす ことにより制御された。刺激はコンピュータ画面上に提 示され, 実験参加者の反応はキーボードとマウスによっ て大力, 記録された.

\section{材料}

漢字 2 字で表記される 72 単語であった (付録を参照). 意味的に関連のある単語が三つで 1 組とされ，合計 24 組が著者により独自に作成された。 24 組中 8 組は行為を 表す単語であった. 3 単語のうち2単語は偶発学習段階 で選択肢の項目として提示され（例えば, “郵便物”と して葉書, 封筒), 残りの 1 単語 (例えば, 切手) は再 認テスト段階で新奇項目として提示された。これらの 24 組と意味的に強い関連を持たない単語が練習試行で 使用された。

単語の組を処理水準と選択条件の組み合わせによる 4 条件に均等に割り当てるため，6組ずつ四つのグループ に分け，4条件への割り当てを実験参加者間でカウンタ バランスした。意味比較条件で選択される単語は実験参 加者ごとに異なったが，それ以外の条件において選択ま たは判断される単語はあらかじめ同一の語に決められて おり ${ }^{2)}$, 画面上の左右に同数ずつ提示された.

判断の種類を指定する文（以後, 指示文）が条件に応 じて用意された。強制選択条件では一つの項目に対して yes/noで答えられるように, “下線の単語はiを含みま すか” (非意味), “下線の単語は行為ですか”（意味）と いう指示文が用いられた。自己選択条件では項目間の相 対比較が必要となるように, “iをより多く含むほうはど ちらですか” (非意味), “よく行う（見る）ほうはどち らですか” (意味) という指示文が用いられた.

妨害課題として，視覚探索課題が用意された。探索画 面は, $9 \times 9$ の仮想マトリクス上のランダムな位置に 81 個の数字（0～80）を配置したものであった.

\section{手続き}

実験はコンピュータルームにおいて集団で行われた.

2） 24 組中 8 組については，ある特定の 1 条件として提示さ れた際に，ほかの条件として提示された場合とは異な る単語が選択や判断の対象として指定されるという誤 りが認められた。
プログラムが保存されたUSBメモリが各実験参加者に 配られ, 課題が実施された。実験参加者には, 文字を表 示させたりキーやタイプ入力を取得するプログラムのデ モンストレーションの一環であること, 画面上に提示さ れる二つの単語のうち一方について yes/noで判断する か, 二つの単語のうち指示文に合う適切な単語を選択す ることを説明した．後の記憶テストについては教示しな かった。“よく行う（見る）ほう”を選択する場合には, 単語自体を目にする頻度ではなく, 単語から意味される 行為を行う（行為ではない場合には, その事物を目にす る）頻度を判断するように注意を促した。実験全体は, 偶発学習段階, 妨害課題段階, 再生テスト段階, 再認テ スト段階 ${ }^{3)}$ より構成され, 所要時間は全体で 20 分程度 であった。

偶発学習段階 実験参加者は 4 条件について 1 試行ず つの練習を行った。 各試行において, まず開始を知らせ る“+”がコンピュータ画面上に 0.5 秒間提示された. 次に, 黒色の画面の上段に白色の指示文が 2 秒間提示さ れた，指示文が消えると，画面上に白色の 2 単語が水平 方向に並んで 4 秒間提示された（yes/no 判断を求める条 件では, 判断対象の単語に下線が引かれていた). その 後, 反応画面へと移行し, 実験参加者は画面上の入力闌 にyes/no判断または選択すべき単語をキーボードから ローマ字入力（漢字変換は不要）するように求められ た.このタイピングは後の再生成績のレベルが低くなり すぎることを防ぐために行われた（伊藤他（2012）で は選択項目を冊子へ記入するよう求めたが, 本研究では プログラムのデモンストレーションの一環としてょり自 然なタイピングとした). yes/no判断を求められた場合 にのみ, 単語入力に先がけて “はい”か“いいえ”のラ ジオボタンをクリックするよう教示された. 最後に Enterキーを押すことで入力が確定され 1 試行が終了し た. 四つの選択条件は全 24 試行中にランダム順に提示 された. 入力内容, 押されたラジオボタン, および反応 画面の提示から Enterキーが押されるまでの時間が記録 された。

妨害課題段階 実験参加者は画面上に一覧提示された 数字を, 0 から順に一つずつできる限り速くかつ正確に マウスでクリックしていくように求められた（制限時間 は3分間).

3）本研究の関心は再生率にあるが, 処理水準の操作を確 認しやすいよう再認テストもあわせて行った. 再認テ スト段階において, 実験参加者は画面上に一つずつ提 示されるテスト項目（合計72単語）について, 偶発学 習段階で見た項目か否かを判断し，“た”キーまたは “南”キーを押して答えるように求められた。再認テス トは直前の再生テストによる影響を受けると推測され るため, 結果は脚注にて報告した. 
Table 1

Mean recall rates, and their standard deviations in parentheses as a function of item types, levels of processing, and orienting tasks

\begin{tabular}{cccccc}
\hline & \multicolumn{2}{c}{ Not semantic } & & \multicolumn{2}{c}{ Semantic } \\
\cline { 2 - 3 } \cline { 5 - 6 } & Force & Choice & & Force & Choice \\
\hline Chosen & $.15(0.17)$ & $.20(0.17)$ & & $.34(0.23)$ & $.42(0.23)$ \\
Non-chosen & $.03(0.08)$ & $.09(0.14)$ & & $.04(0.09)$ & $.36(0.23)$ \\
\hline
\end{tabular}

再生テスト段階 実験参加者は偶発学習段階で見た単 語を，選んだ（またはyes/noの判断を行った）か否か にかかわらず，自由な順序でできる限り思い出して画面 上の入力欄に 1 単語ずつキーボードからローマ字入力 (漢字変換は不要) するように求められた（制限時間は 4 分間). 入力された項目は Enterキーが押されると入力 欄から消去され, 次の単語の入力待ち状態となった.

その後, 再認テスト段階の終了後に, 実験参加者は偶 発学習段階の時点で記憶テストを予期していたかを尋ね られた。同時に，性別，年齢も尋ねられ，データの提供 に同意する場合にはチェックボックスをクリックするよ うに求められた．同意を得られた場合にのみ，これらの データが各個人を特定できない形でUSBメモリに保存 され，分析の対象となった.

\section{結果}

偶発学習段階で課題が適切に行われた試行（全実験参 加者の全試行に対する約 $92 \%$ ）のみを分析の対象とし た. 以下では，偶発学習段階において判断されたり選択 された項目 (選択項目) と, それ以外の項目（非選択項 目）とに分けて，再生率 (および再認率 ${ }^{4)}$ ) を算出した. 再生率とは, 偶発学習段階で提示された項目のうち再生 された項目の割合であり，その平均（以後， $M$ ）につい て処理水準と選択条件を参加者内要因とした分散分析を 行った（Table 1).

\section{選択項目}

分散分析の結果，処理水準の主効果 $(F(1,52)=64.98$, $M S e=0.04, p<.01)$, および選択条件の主効果（F(1, $52)=4.93, M S e=0.05, p<.05 ）$ がそれぞれ有意であっ た. 非意味水準 $(M=.17, S D=0.17)$ よりも意味水準 $(M=.38, S D=0.23)$ での再生率が高く, 本研究におい て処理水準効果が確認された。 また, 強制選択条件（M $=.24, S D=0.22)$ よりも自己選択条件 $(M=.31, S D=$ 0.23）での再生率が高く, 自己選択効果が認められた. 交互作用は有意ではなかった $(F<1)$.

\section{非選択項目}

分散分析の結果, 処理水準の主効果 $(F(1,52)=$ $54.83, M S e=0.02, p<.01)$, 選択条件の主効果 $(F(1$,
$52)=87.82, M S e=0.02, p<.01)$, および交互作用（F(1, $52)=51.50, M S e=0.02, p<.01 ）$ がそれぞれ有意であっ た. 単純主効果の検定の結果, 自己選択条件で処理水準 効果が得られ $(F(1,52)=65.13, M S e=0.03, p<.01)$, また，水準にかかわらず強制選択条件よりも自己選択条 件で再生率が高かった（非意味 $F(1,52)=7.49, M S e=$ $0.01, p<.01$; 意味 $F(1,52)=99.98, M S e=0.03, p<.01)$.

\section{考察}

記憶の自己選択効果を説明するために提案された結合 処理説 (Hirano \& Ukita, 2003), 多重手がかり説 (Watanabe, 2001; Watanabe \& Soraci, 2004), および統 合仮説 (Toyota, 2013; 豊田・小林, 2009; 豊田他, 2007）では, 項目を相対比較する過程で, 選択項目を 何らかの対象に関連づけることが再生を促すと想定して いる．選択項目を関連づける対象を明確にすることは確 かに重要である。しかし，その基礎として本研究では， 項目を意味水準で処理すること自体が自己選択効果の生

4）再認テストの結果は以下のとおりであった。偶発学習 段階で提示された項目のうち, 再認テスト段階で“見 た”と正しく反応された項目の割合 (Hit率) を条件別 に求めた。 選択項目に対する Hit率は全体に高かった $(M \geqq .82)$. 処理水準と選択条件を参加者内要因とした 分散分析を行った結果, 処理水準の主効果 $(F(1,52)=$ $43.17, M S e=0.02, p<.01)$ のみが認められ, 選択条件 の主効果 $(F(1,52)=1.58)$, および交互作用 $(F(1$, $52 ＝ 1.41 ）$ は有意でなかった. 一方, 非選択項目に対 する Hit率は選択項目よりも全体に低かった。分散分析 の結果, 処理水準の主効果 $(F(1,52)=72.47, M S e=$ $0.03, p<.01)$, 選択条件の主効果 $(F(1,52)=241.74$, $M S e=0.04, p<.01)$ ，および交互作用 $(F(1,52)=17.15$, $M S e=0.03, p<.01 ）$ がそれぞれ有意であった. 単純主 効果の検定の結果, 水準によらず自己選択条件で再生 率がより高く（非意味 $F(1,52)=74.90, M S e=0.04, p<$ .01 ; 意味 $F(1,52)=243.05, M S e=0.03, p<.01)$, 選択条 件によらず処理水準効果が得られた（強制選択 $F(1$, $52)=10.83, M S e=0.03, p<.01$; 自己選択 $F(1,52)=$ $83.75, M S e=0.03, p<.01)$. なお, 再認テスト段階で新 しく提示された項目のうち，“新奇”と正しく反応され た項目の割合（correct rejection率）についても同様の 分散分析を行ったが, いずれの効果も有意ではなかった $\left(F_{\mathrm{s}}<1\right)$. 
起にどの程度影響するかを検討した。

本研究の結果, 選択項目の再生率において有意な処理 水準効果が認められた（再認Hit率でも同様）ため, 操 作は確実に行わ机たと言えよう. 選択条件の主効果も有 意であり, 処理水準との交互作用は認められなかったこ とから, 自己選択効果が処理水準効果とは独立であると いえる.つまり, 比較の過程で項目の“意味”を処理し たことのみから自己選択効果が説明されるとは言えな い.それぞれの水準における強制選択条件と自己選択条 件に注目すると，選択条件間では処理の水準が統制され ており, 項目に対する判断課題を行う点でも統制されて いた. そのため, 自己選択効果が処理水準や判断課題の 有無ではなく, 項目間の相対比較に基づいて生起する可 能性がより明確に示された。

自己選択効果は選択項目だけではなく非選択項目の再 生率においても認められた。この理由として, 非選択項 目は相対比較の過程で選択項目と一部共通する処理を受 けたために再生されやすくなったと考えることができ る.ただし, 非選択項目の再生率は選択項目ほどには高 くなく ${ }^{5)}$, 非選択項目が選択項目と全く同じ処理を受け たとは言えない。この項目間の再生率の差には, タイピ ングの有無による差も含まれている可能性がある. 非選 択項目の再生率においても自己選択効果が認められた別 の理由として, 強制選択条件においてyes/no判断の対 象とはならなかった項目が, 注意を向けられる必要がな かったためにほとんど再生されなかったとも考えられ る. 判断対象外の項目の再生率は処理水準によらず低 かった $(M \leqq .04)$.このように非選択項目については, 強制選択条件において一様に低い再生率が, 選択条件と 処理水準の交互作用を生じさせた可能性がある.

本研究では, 非意味的な比較よりも意味的な比較をし た場合に高い再生率が得られたのに対して, 伊藤他 （2012，実験2）では水準による差が認められなかった. この違いを生じさせた理由としては, 先行研究に対して 本研究では処理水準の操作が確実に行われたことと, 統 計的にも差が検出されやすかったことが考えられる. 後 者について, 具体的には, 本研究では参加者数が多かっ たこと, 再生率のレベルが高くなり過ぎなかったことが 挙げられる. 再生率の基本的なレベルを反映する指標と して, 比較が行われず意味水準での処理も行われない条 件に注目すると, 本研究（非意味強制選択条件 $M=.15$ ） は伊藤他（強制選択条件 $M=.25 ）$ を下回っていた。本

5）自己選択条件について, 項目（選択, 非選択）と処理 水準 (非意味, 意味) を要因とした分散分析の結果, 項目の主効果 $(F(1,52)=23.16, M S e=0.02, p<.01)$, 処理水準の主効果 $(F(1,52)=57.35, M S e=0.06, p<.01)$ がそれぞれ有意であり, 交互作用は認められなかった $(F(1,52)=2.65)$.
研究と伊藤他 (2012, 実験2) では, 偶発学習事態で意 味的に関連のある単語材料が使用され，3分間の遅延後 に選択項目と非選択項目の自由再生テストが行われた点 で共通であった，ただし，本研究では再生すべき項目数 がより少なく, 非意味強制選択条件では単に指定された 単語を答えるだけではなくyes/no判断もあわせて行っ たにもかかわらず, 先行研究よりも低い成績レベルで あった。

本研究の残した課題として, 意味水準の自己選択条件 での判断の質的な違いがその他の条件よりも高い再生率 をもたらした可能性は否定できない。この条件では自ら の行為の頻度をエピソード記憶から参照することで答え を決めなければならなかったが, ほかの条件ではより一 般的な知識に基づく判断が行われたと推測される。意味 水準の自己選択条件では項目が実験参加者自身の個人的 記憶に関連づけられ（Rogers, Kuiper, \& Kirker, 1977), 一般的な知識に基づく意味的な比較を行うよりも豊富な 情報が符号化され, 後の再生を助けたかもしれない.こ の説明の可能性は今後検討する余地があるが, 本研究の 非意味水準の自己選択条件（個人的なエピソードの参照 が不要）においても同じ水準の強制選択条件に対する再 生の促進が認められたことを考えると, 相対比較処理が 記憶を促す可能性が否定されるわけではない。

自己選択効果との共通性が推測される生成効果（Slamecka \& Graf, 1978）に関しては, 音韻的な規則で単語 の生成を求めた場合にも意味的な規則での生成を求めた 場合と同様に記憶が促進されるという（ただし，高齢の 実験参加者を除く)。音韻的生成条件における記憶の促 進の理由は, 生成の処理そのものではなく, 実験参加者 が生成後に自発的に行う意味的な確認（一部が欠けた状 態で提示された単語が, 生成によって意味を持つ単語に なったか, 手がかり語とどのような関係か) の処理に基 づいていた可能性が指摘されている（Taconnat \& Isingrini, 2004). しかし, 本研究では初めから完全な形で 単語が提示され意味的な確認は不要であったため, この 指摘は当てはまらないと考えられる。それにもかかわら ず非意味水準の自己選択による記憶の促進が認められた 本研究の結果は, 相対比較の処理そのものに基づいて記 憶が促進される可能性を示唆する。

今後, 自己選択効果の生起を理解するためには, 相対 比較に含まれるどのような処理が再生を促すかを明確に していくことが求められる。すでに提唱されている結合 処理説・多重手がかり説 (Hirano \& Ukita, 2003; Watanabe \& Soraci, 2004), おょび統合仮説 (Toyota, 2013) の 妥当性と一般性を明らかにする必要がある. 加えて, こ れらの説明と, 比較の過程において項目を共通の次元で 整列させる処理 (Gentner \& Markman, 1994; Mather, Knight, \& McCaffrey, 2005; Zhang \& Markman, 1998, 
2001）や，共通性に基づいて項目間を区別する示差性 (distinctive) 処理（Jacoby, Craik, \& Begg, 1979; Hunt, 2006; Hunt \& Smith, 1996）との関係を明確にすること も望まれる.

\section{引用文献}

天野成昭・近藤公久 (1999). NTTデータベース シリーズ日本語の語彙特性（第 1 巻） 三省堂 (Amano, S., \& Kondo, T.)

Craik, F. I. M., \& Lockhart, R. S. (1972). Levels of processing: A framework for memory research. Journal of Verbal Learning and Verbal Behavior, 11, 671-684.

Einstein, G. O., \& Hunt, R. R. (1980). Levels of processing and organization: Additive effects of individual-item and relational processing. Journal of Experimental Psychology: Human Learning and Memory, 6, 588-598.

Gentner, D., \& Markman, A. B. (1994). Structural alignment in comparison: No difference without similarity. Psychological Science, 5, 152-158.

平野哲司（2000）。記憶における自己選択効果一 概説 人文論究 (関西学院大学), 49, 83-100. (Hirano, T. (2000). The self-choice effect in memory: A review. The Journal of the Literary Association of Kwansei Gakuin University, 49, 83-100.)

Hirano, T., \& Ukita, J. (2003). Choosing words at the study phase: The self-choice effect on memory from the viewpoint of connective processing. Japanese Psychological Research, 45, 38-49.

Hunt, R. R. (2006). The concept of distinctiveness in memory research. In R. R. Hunt, \& J. B. Worthen (Eds.), Distinctiveness and memory. New York: Oxford University Press, pp. 3-25.

Hunt, R. R., \& Smith, R. E. (1996). Accessing the particular from the general: The power of distinctiveness in the context of organization. Memory \& Cognition, 24, 217-225.

伊藤真利子・綾部早穂 - 菊地 正 (2012). 自己 選択時の比較過程による記憶促進効果 認知心 理学研究, 10, 37-47.

(Itoh, M., Ayabe-Kanamura, S., \& Kikuchi, T. (2012). Memory facilitation effect yielded by comparison process during self-choice. The Japanese Journal of Cognitive Psychology, 10, 37-47.)

Jacoby, L. L., Craik, F. I., \& Begg, I. (1979). Effect of decision difficulty on recognition and recall. Journal of Verbal Learning and Verbal Behavior, 18, 585-600.
Mather, M., Knight, M., \& McCaffrey, M. (2005). The allure of alignable: Younger and older adults' false memories of choice features. Journal of Experimental Psychology: General, 134, 38-51.

Monty, R. A., Perlmuter, L. C., Libon, D., \& Bennet, T. (1982). More on contextual effects on learning and memory. Bulletin of the Psychonomic Society, 20, 293-296.

Perlmuter, L. C., \& Monty, R. A. (1982). Contextual effects on learning and memory. Bulletin of the Psychonomic Society, 20, 290-292.

Perlmuter, L. C., Monty, R. A., \& Kimble, G. A. (1971). Effect of choice on paired-associate learning. Journal of Experimental Psychology, 91, 47-53.

Rogers, T. B., Kuiper, N. A., \& Kirker, W. S. (1977). Self-reference and the encoding of personal information. Journal of Personality and Social Psychology, 35, 677-688.

Slamecka, N. J., \& Graf, P. (1978). The generation effect: Delineation of a phenomenon. Journal of Experimental Psychology: Human Learning and Memory, 4, 592-604.

Taconnat, L., \& Isingrini, M. (2004). Cognitive operations in the generation effect on a recall test: Role of aging and divided attention. Journal of Experimental Psychology: Learning, Memory, and Cognition, 30, 827-837.

高橋雅延（1989）。記憶における自己選択効果 京都大学教育学部紀要, 35, 211-221.

(Takahashi, M. (1989). The self-choice effect in learning and memory. Kyoto University Research Studies in Education, 35, 211-221.)

Takahashi, M. (1992). Memorial consequences of choosing nonwords: Implication for interpretations of the self-choice effect. Japanese Psychological Research, 34, 35-38.

高橋雅延（1993）。再認記憶における自己選択効 果と学習材料の有意味度 京都橘女子大学研究 紀要, 20, 130-140.

(Takahashi, M. (1993). The role of self-choice in recognition memory as a function of the meaningfulness of the materials. Memoirs of Kyoto Tachibana Women's University, 20, 130140.)

高橋雅延（1997）. 記憶における符号化方略の研 究 北大路書房

(Takahashi, M.)

Toyota, H. (2013). The self-choice effects on memory and individual differences in emotional intelligence. Japanese Psychological Research, 
$55,45-57$.

豊田弘司・小林千春（2009）。意図記憶における 自己選択効果と統合仮説 奈良教育大学紀要, 58, 33-40.

(Toyota, H., \& Kobayashi, C. (2009). Selfchoice effects in intentional memory and integration hypothesis. Bulletin of Nara University of Education, 58, 33-40.)

豊田弘司・小林加奈・平野哲司（2007）。偶発記 憶における自己選択効果と統合仮説 奈良教育 大学紀要, 56, 31-39.

(Toyota, H., Kobayashi, K., \& Hirano, T. (2007). Self-choice effects in incidental memory and integration hypothesis. Bulletin of Nara University of Education, 56, 31-39.)

Watanabe, T. (2001). Effects of constrained choice on memory: The extension of the multiple-cue hypothesis to the self-choice effect. Japanese Psychological Research, 43, 98-103.

渡邊兼行（2011）。自己選択効果研究における課
題と展望 仙台白百合女子大学紀要, 15, 7387.

(Watanabe, T. (2011). Issues and perspectives on research in the self-choice effect. The Journal of Sendai Shirayuri Women's College, 15, 7387.)

Watanabe, T., \& Soraci, S. A. (2004). The selfchoice effect from a multiple-cue perspective. Psychonomic Bulletin \& Review, 11, 168-172.

Zhang, S., \& Markman, A. B. (1998). Overcoming the early entrant advantage: The role of alignable and nonalignable differences. Journal of Marketing Research, 35, 413-426.

Zhang, S., \& Markman, A. B. (2001). Processing product unique features: Alignability and involvement in preference construction. Journal of Consumer Psychology, 11, 13-27.

（2012年 8 月 27 日受稿, 2012 年 12 月 11 日受理) 
付 録

偶発学習段階で対提示された単語材料

天野・近藤（1999）による単語親密度（1：低〜 7 : 高）は，本研究で使用された下記の単語について， $M=5.7(S D=$ 0.4）であった（ただし，賞賛，振込，引出，折紙については，同表記の親密度が不明であった）。下記の単語のほか に，それぞれの対で意味的に関連するもう一つの単語が再認テスト段階での新奇項目として使用された。

\begin{tabular}{rrr}
\hline 1 & 賞賛 & 激励 \\
2 & 読解 & 要約 \\
3 & 写真 & 油絵 \\
4 & 椎莫 & 大根 \\
5 & 横笛 & 尺八 \\
6 & 月食 & 日没 \\
7 & 依頼 & 承諾 \\
8 & 買物 & 洗濯 \\
9 & 袁児 & 学童 \\
10 & 花束 & 宝石 \\
11 & 雨蛙 & 大蛇 \\
12 & 玄関 & 書斎 \\
13 & 問診 & 検温 \\
14 & 振込 & 引出 \\
15 & 地下 & 山頂 \\
16 & 砂糖 & 味噌 \\
17 & 手袋 & 帽子 \\
18 & 箸置 & 茶碗 \\
19 & 納税 & 労働 \\
20 & 綱引 & 競走 \\
21 & 葉書 & 封筒 \\
22 & 手帳 & 辞書 \\
23 & 風船 & 折紙 \\
24 & 講堂 & 正門 \\
\hline
\end{tabular}

